\title{
EXAMINING CROWDING USING A REAL THREE-DIMENSIONAL EXPERIMENTAL SETUP
}

\author{
Lisa Valentina Eberhardt ${ }^{\#}$ and Anke Huckauf \\ General Psychology, Institute of Psychology and Education, Ulm University, Albert-Einstein-Allee 47, 89069 UIm, GERMANY \\ \#Corresponding author, lisa.eberhardt@uni-ulm.de
}

Communicated by Ivars Lācis

\begin{abstract}
The phenomenon of impaired recognition of peripherally presented visual targets, when flanked by similar stimuli, is referred to as crowding. Studies in a two-dimensional space have shown that lateral distances are critical: the extent of crowding depends on eccentricity of the target stimulus and on the spacing between target and flanking stimuli. The question of whether also distances in depth affect crowding was until now usually investigated using virtual depth. However, virtual and real depth differ, for example with respect to the accommodation-vergence alignment and to effects of blur. Thus, we made an attempt to study crowding in real depth. In our experimental setup, real depth is implemented by two screens, observed via a semi-transparent mirror. Thus, moving the two screens along the line of sight allows simultaneous stimulus presentation with real depth differences. In a first validation study with 18 participants, a fixation cross was fixed in a depth of $190 \mathrm{~cm}$. Single and flanked Landolt rings were presented in $2^{\circ}$ of eccentricity in the same depth as fixation, or in front of $(170 \mathrm{~cm})$, or behind $(215 \mathrm{~cm})$ the fixation depth. Results concerning recognition performance show a similar extent of crowding for flanked targets presented in front of, or behind the fixation depth, and flanked targets in the fixation depth. But, concerning reaction time, the difference between isolated and flanked targets was reduced in defocused depths compared to the fixation depth. That is, reaction time toward flanked targets in the fixation depth was higher than in front of, or behind the fixation depth. With the experimental setup, crowding successfully was induced in different real depths. In further studies, the influence of target and flankers in divergent depths on crowding will be investigated.
\end{abstract}

Key words: crowding, flanker, three-dimensional experimental setup, real depth.

\section{INTRODUCTION}

The recognition of peripheral visual target stimuli is reduced substantially, when they are flanked by similar stimuli, in comparison to when they are presented in isolation (Bouma, 1970). This phenomenon is referred to as crowding effect. Usually, the extent of crowding is measured as the difference in recognition performance of isolated and flanked targets. The impairment in recognisability of flanked in comparison to isolated targets is assumed to be driven mainly by lower level cognitive processes in the processing of peripheral patterns or objects (Levi, 2008). However, there is increasing evidence indicating that also higher level cognitive processes are relevant (e.g. Huckauf, 2007; Huckauf and Nazir, 2007; Bernard et al., 2012).

In particular lateral distances affect the extent of crowding. Namely, these lateral distances are the target eccentricity and the spacing between the target and the flanking stimuli (Bouma, 1970). Increasing the eccentricity of a single target stimulus decreases its recognition performance. This is partly due to the decline of visual acuity with increasing eccentricity. However, this decline can by far not explain the huge decline in crowding with increasing eccentricity (e.g., Strasburger et al., 2011). Crowding also varies with spacing: increasing the spacing between target and flankers results in increasing target recognisability, that is, in decreased crowding. To which extent target selection processes contribute to crowding is under discussion (e.g., Huckauf and Heller, 2002a; 2002b; Strasburger et al., 2011; Strasburger and Malania, 2013).

Bouma (1970) found that target eccentricity and spacing interact. Critical spacing refers to the target to flanker distance for a given eccentricity, at which the recognition of flanked targets is equal to isolated targets. Thus, at this critical spacing there occurs no crowding anymore, that is, target recognition performance for flanked and isolated targets does not differ. This window, in which crowding occurs, thus the spatial extent of crowding, increases proportionally with increasing target eccentricity (Pelli and Tillman, 2008). 
The reported results about lateral distances, namely eccentricity and spacing, were replicated in a large amount of studies. In the classical attempts, crowding was investigated mainly with letters presented on the horizontal meridian (Korte, 1923; Bouma 1970). Later, it was also shown to exist on the vertical meridian, although crowding effects were smaller in the vertical axis (see Strasburger, 2005; Levi, 2008; Pelli and Tillman, 2008, for reviews). This raises the question of whether crowding is affected not only by lateral distances on a plane, but also by distances in depth. In other words, how is the spatial extent of crowding characterised in three-dimensional space? Since the most of the studies on crowding were conducted on a two-dimensional plane, only little is known about the influence of depth.

There exist already a few studies, which deal with the influence of depth on crowding (Kooi et al., 1994; Felisberti et al., 2005; Astle et al., 2014). Their results indicate that crowding seems to be smaller when the flankers are presented either in front of (Felisberti et al., 2005; Astle et al. 2014) or behind a target (Kooi et al., 1994; Felisberti et al., 2005; Astle et al., 2014), compared to when all stimuli are presented in the same depth plane. Furthermore, similar to lateral spacing, crowding seems to decrease with increasing distance between target and flankers in depth (Astle et al., 2014).

However, in all these former studies, stimuli were presented in virtual depth. Importantly, the perception of virtual and real depth differs remarkably. Apart from object driven depth cues (e.g., size, occlusion, shading), perception of depth depends on the information of the visual system itself, that is, on the state of vergence and accommodation. Thus, studying crowding in virtual depth can provide only an incomplete picture about the influence of depth. The main difference in virtual compared to real depth is the absence of defocus blur. Virtual depth perception is achieved by manipulating binocular disparity, which is known as the difference in retinal image location between the left and right eye (Howard and Rogers, 2012). This leads to an important difference between virtual and real depth, that is, the alignment of accommodation and vergence (Lambooij et al., 2009). In real depth, accommodation and vergence are aligned, and both are oriented to the fixated object. However, in virtual depth accommodation and vergence are disentangled. For a sharply seen picture in virtual depth, accommodation needs to be focused on the display plane, whereas vergence is moved to the objects perceived in front of or behind the display plane (Hoffman et al., 2008). This also implies, that, whereas in real depth defocused objects are characterised by retinal image blur, in virtual depth, they are not. In a real scenery defocus blur increases with increasing distance from the fixation depth and is assumed to serve as a depth cue. In contrast, all stimuli in virtual depth are presented on one plane and thus, defocus blur is missing (Hoffman et al., 2008). Thus, studying crowding in real depth offers the opportunity to additionally investigate the influence of defocus blur, which might produce impairments, similar to the impairments produced by the decline in visual acuity in the lateral periphery.

Taken together, the former studies conducted in virtual depth allows only to conclude to possible effects of binocular disparity on crowding, but exclude the investigation of the influence of other important physiological depth cues, such as defocus blur. Thus, since virtual and real depths differ, the question remains of how crowding is affected by real depth distances.

One first attempt to classify the options of possible crowded stimulus configurations in depth, is to apply the findings about lateral distances in depth. Analogously to eccentricity, the distance of all stimuli could be varied in depth, in other words, all stimuli could be defocused in front of, or behind the fixation depth plane. Also, applying the finding of spacing in depth, analogously, the spacing between target and flanking stimuli could be varied in depth. One example for such a depth-spacing could be defocusing only the flankers or the target in relation to the fixation depth, as it was done in former studies using virtual depth (Astle et al., 2014; et al., 2005; Kooi et al., 1994). The focus of the current study is on developing and exploring a paradigm, in which the distance of all stimuli in relation to the fixated distance was varied analogously to eccentricity. Thus, in contrast to the former studies in virtual depth, we varied not target-toflanker distance in depth (analogous to spacing), but the distance of fixation depth and depth of crowded stimuli (analogous to eccentricity).

To display real depth we adopted an experimental setup described in Rinkenauer and Grosjean (2008). They presented stimuli on two screens, which were observed via a semi-transparent mirror, resulting in the perception of all presented stimuli in one line of sight. They conducted a flanker task in the central visual field, to map the distribution of focused visual attention in three-dimensional space. Their results indicated less target-flanker interactions for a large target-to-flanker spacing, when flankers were defocused in depth. These results are similar to the above outlined findings on peripheral crowding in virtual depth.

The objective of the present study was twofold. First, we aimed at implementing the crowding paradigm in a real three-dimensional setup, using two screens, observed via a semi-transparent mirror, as described in Rinkenauer et al. (2008)'s paper. Thus, the various prospects of our implementation will be pointed out. Second, the current study is a first attempt on investigating stimulus processing in isolated and flanked context in defocused depths, compared to the fixation depth. In other words, we varied the stimuli's distances in depth analogously to eccentricity. Our results indicate that crowding occurs to a similar extent in the range of tested depths. However, when further analysing the errors, we find different patterns of confusions for flanked stimuli in the fixation depth and in defocused depths. Furthermore, regarding reaction times, lower response times for defocused stimuli were found. 


\section{MATERIALS AND METHODS}

Participants. Eighteen psychology students (10 female; mean age \pm SD was $25 \pm 6$ years) of Ulm University participated in the experiment. According to a screening with a Landolt test chart prior to testing, visual acuity was normal for all participants both monocular and binocular ( 0.8 or better in decimal units) at a distance of $5 \mathrm{~m}$. According to the TNO Stereo Test all participants had normal stereoscopic vision (Med = 60 arc min; Min $=240$ arc min, Max = 15 arc min). All participants signed informed consent prior to the experiment and received partial course credit for their attendance.

Apparatus. Stimuli were presented on two 26-inch NEC MultiSync LCD screens (resolution: $1440 \times 900$; refresh rate: $60 \mathrm{~Hz}$ ). Simultaneous stimulus presentation was controlled by MATLAB (Version 7.9) and Psychtoolbox (Version 3; Brainard, 1997), running on a Windows XP operating system with a Matrox M9138 LP graphics device. As can be seen in Figure 1, a semi-transparent mirror was mounted in an angle of $45^{\circ}$ in front of the participant. One of the screens (referred to as Screen 1 in Figure 1) was mounted behind the mirror, in the gaze direction of the participant. The second screen (referred to as Screen 2 in Figure 1) was mounted on the right hand side of the semitransparent mirror. Thus, stimuli presented on the second screen were reflected by the mirror to the gaze direction of the participant (illustrated as Screen 2' in Figure 1). By mounting the two screens in different distances to the participant, real depth differences can be displayed. Throughout the experiment Screen 2 was fixed in a distance of 190 $\mathrm{cm}$, displaying the fixation depth. Screen 1 was adjustable in depth. Since we decided to adapt depth differences to the measurement unit of the eye, diopters, Screen 1 was mounted either in a distance of $170 \mathrm{~cm}$ or in a distance of $215 \mathrm{~cm}$. These distances correspond to a difference of about 0.06 diopters between Screen 1 and Screen 2 in both directions. Participants responded on a costmary keyboard, in which the numeric keypad was modified in that only the arrow keys (digits 2, 4, 6, 8) and the central key (digit 5) remained.

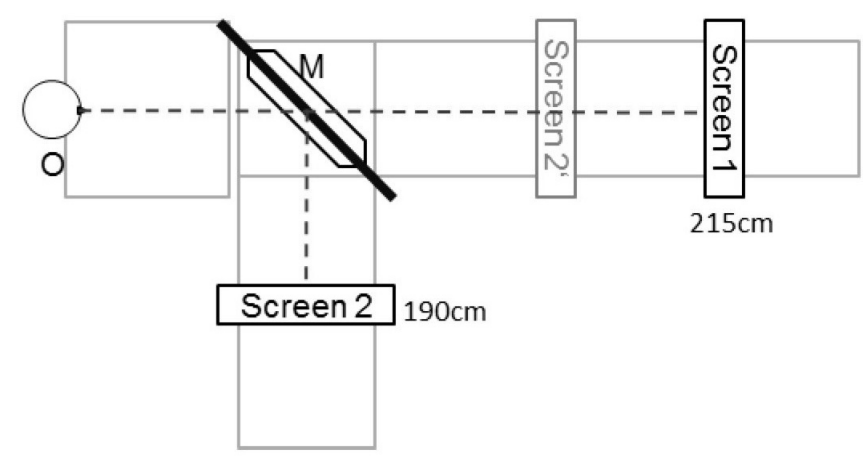

Fig. 1. Experimental setup in one depth condition. Participants $(\mathrm{O})$ observe stimulus presentation on Screen 1 directly. Stimuli on Screen 2 are reflected by the semi-transparent mirror (M). Screen 2' indicates the perceived position of the reflection. Throughout the experiment, Screen 2 was fixed in a distance of $190 \mathrm{~cm}$, while Screen 1 was adjustable in depth, mounted either at $170 \mathrm{~cm}$ or at $215 \mathrm{~cm}$ as depicted in the scheme.
Stimulus material and design. A bright fixation cross (white; $160 \mathrm{~cd} / \mathrm{m}^{2}$ ) of the size of $0.6^{\circ}$ of visual angle with a line width equal to the Landolt stimuli, was presented in the centre of Screen 1 in a distance of $190 \mathrm{~cm}$. Isolated or flanked, bright (white; $160 \mathrm{~cd} / \mathrm{m}^{2}$ ) Landolt rings on a dark (black; $0.2 \mathrm{~cd} / \mathrm{m}^{2}$ ) background served as stimuli. Stimuli were presented either in the fixation plane at $190 \mathrm{~cm}$ (Screen 1), or in front of the fixation plane at $170 \mathrm{~cm}$, or behind the fixation plane at $215 \mathrm{~cm}$ (Screen 2). From the participant's viewpoint, stimulus presentation in all depth conditions appeared as outlined in Figure 2. The size of the stimuli was $0.6^{\circ}$ of the visual angle in all conditions. The targets were presented in an eccentricity of $2^{\circ}$ of visual angle either in the left or in the right visual field. In flanked conditions targets were flanked to the left and right side. Centre-to-centre spacing of target and flankers was $1^{\circ}$ of the visual angle. The target rings were opened either left, right, up or down. The opening direction of the flankers was chosen randomly, under the constraint that the opening direction of all three rings differed. This allowed us to separate errors into confusions with one of the flankers and false answers. Thus, in total 2 (context: isolated/flanked) $\times 2$ (visual field $) \times 4$ (ring opening $) \times 3$ (depths $) \times 10$ (repetitions $)=$ 480 trials were conducted.

As dependent variables, recognition performance, confusion errors, and reaction times were analysed. Recognition performance is the percentage of correct answers according to the target ring's opening direction. Analogously, inward and outward confusions were defined as the percentage of responses matching to the inward (between fixation cross and target ring) or outward (ring most distant from fixation cross) flanker. Reaction time was estimated as the duration from stimulus onset until correct answer keypress.

Procedure. Prior to the experiment, visual acuity and stereoscopic vision was screened. For the experiment, participants sat in a dimmed room (illumination approx. 1.7 1x), their head fixed in a head-chin rest. Participants could adapt to the lightning conditions during the instructions and the training block. In the training block of 82 trials, the participants were made familiar with the task and answering behaviour. The main experiment consisted of two blocks. In one block Screen 1 was mounted at $170 \mathrm{~cm}$ in front of the fixation depth, in the other block Screen 1 was mounted at $215 \mathrm{~cm}$ behind the fixation depth. The trials which were presented in the fixation depth were split and half of them were presented in each block. Thus, the two blocks consisted of 240 randomised trials each. Nine participants started with Screen 1 in a distance of $170 \mathrm{~cm}$; the other nine participants started with Screen 1 in a distance of $215 \mathrm{~cm}$.

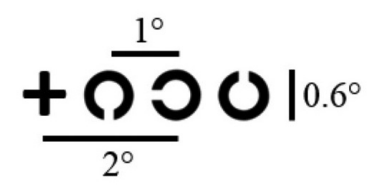

Fig. 2. Stimulus configuration from a participant's viewpoint. The Landolt ring in the middle is target ring at an eccentricity of $2^{\circ}$, surrounded by two flanking Landolt rings with a spacing of $1^{\circ}$. The size of the fixation cross and all stimuli was adjusted to $0.6^{\circ}$ of visual angle in all depth conditions. 
By pressing the central key, a trial started with the presentation of the fixation cross. Participants were instructed to fixate the cross, whenever it was present. After holding the key for $500 \mathrm{~ms}$, the stimuli appeared on the left or right side of the fixation cross. Stimuli and fixation cross disappeared after $20 \mathrm{~ms}$ of stimulus presentation. Participants were instructed to react as fast and correct as possible according to the opening direction of the target ring, by releasing the central key and pressing the respective arrow key on the modified number pad on the keyboard. When no answer was given within $1 \mathrm{~s}$ after stimulus onset, an error sound rang out, and the answer was marked as a missing. The next trial started again with the presentation of the fixation cross by holding the central key.

\section{RESULTS}

Data analysis. Since the experiment run in MATLAB, also pre-processing of the data was done with MATLAB R2014b (MathWorks, Inc.). For inferential statistical analysis, IBM SPSS Statistics Version 22 (IBM Corp.) was used. One person was excluded due to an insufficient number of analysable trials, caused by too slow reactions. Thus, final data analysis was done with a sample of 17 participants. Although some variables were not normally distributed, we conducted repeated measures ANOVAs to test differences between means, because the ANOVA allows multi-factorial comparisons and is robust against the violation of the assumption of normality (Bortz and Schuster, 2010).

Recognition performance. To test whether there were differences in crowding effects between depths, a 2 (context: isolated/flanked) $\times 3$ (depth: 170/190/215) repeated measures ANOVA was conducted on recognition performance. The results only revealed a significant main effect of context. Recognition performance for flanked targets was significantly lower than for isolated targets, $\mathrm{F}(1.16)=71.66$, $p=0.001, \eta^{2}=0.82$, and for all tested depths: in the fixation distance of $190 \mathrm{~cm}$ mean recognition performance $( \pm \mathrm{SD})$ was $95 \%( \pm 10 \%)$ for isolated and $61 \%( \pm 18 \%)$ for flanked targets. In a distance of $170 \mathrm{~cm}$, mean recognition performance $( \pm$ SD) was $95 \%( \pm 7 \%)$ for isolated and $62 \%$ $( \pm 14 \%)$ for flanked targets. In a distance of $215 \mathrm{~cm}$, mean recognition performance $( \pm \mathrm{SD})$ was $95 \%( \pm 11 \%)$ for isolated and $63 \%( \pm 19 \%)$ for flanked targets. For depth and interaction between context and depth the ANOVA revealed no effects, $\mathrm{F}(2.32)=0.061, p=0.94$, and $\mathrm{F}(2.32)=0.26$, $\mathrm{p}=0.77$, respectively. Taken together, flanking the target rings affected recognition performance in all the tested depths similarly. Thus, our results of recognition performance replicate the classical crowding effect in all tested depths. Figure 3 shows the crowding effect for all tested depths, calculated by subtracting recognition performance for flanked targets from recognition performance for isolated targets.

Confusion errors. To test whether the response pattern between depths differs, we compared confusion errors between depths. Confusion errors were split into inward and

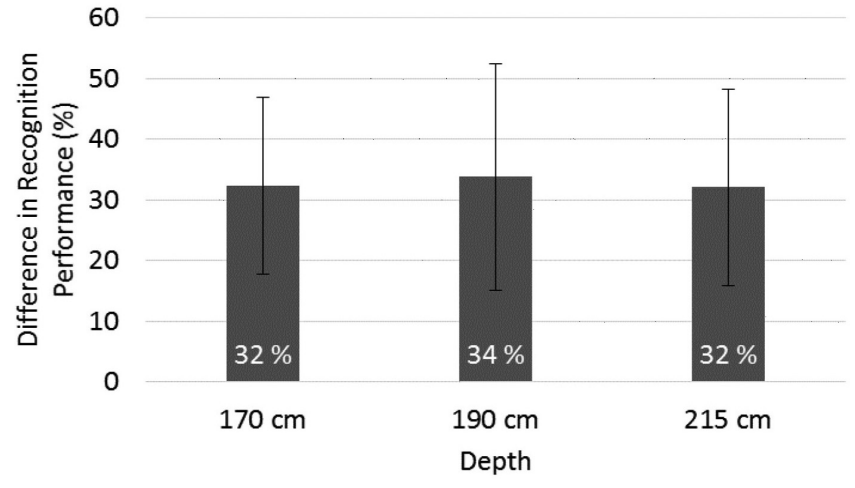

Fig. 3. Crowding effects in respective depths. The effects were calculated by subtracting recognition performance for flanked targets from recognition performance for isolated targets, separately for each depth condition. Error bars refer to standard deviations of the difference values. The depth of fixation was at $190 \mathrm{~cm}$.

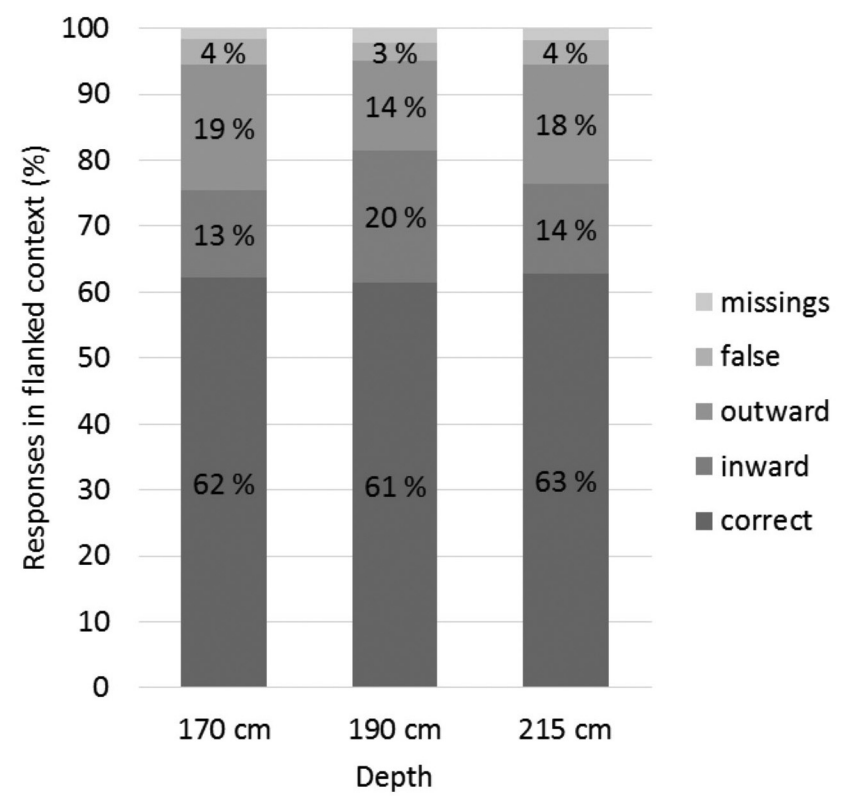

Fig. 4. Distribution of responses in flanked context. Missings refer to the percentage of responses, which were not given within $1 \mathrm{~s}$ after stimulus onset. False refers to the percentage of false answers. Inward and outward refer to the percentage of confusion errors, thus, to responses that match to the opening direction of the inward or outward flanker. Correct refers to the percentage of correct target identifications. The depth of fixation was at $190 \mathrm{~cm}$.

outward confusions, that is, responses, which matched not to the target, but to the inward or outward flanker. The percentage of inward and outward confusions, in relation to the overall distribution of responses, is given in Figure 4. A 2 (side: inward/outward) $\times 3$ (depth: 170/190/215) repeated measures ANOVA was conducted on the percentage of confusion errors in the overall trials. The analysis showed neither an effect of side, $\mathrm{F}(1.16)=2.14, p=0.16$, nor of depth, $\mathrm{F}(1.32)=0.64, p=0.54$. However, there was a tendency toward an interaction between side and depth, $\mathrm{F}(2.32)=3.26$, $p=0.08$ (Greenhouse-Geisser corrected, due to rejection of sphericity by a Mauchly-Test), descriptively indicating more inward confusions at the fixation depth, whereas outward confusions were more likely in defocused depths (compare Fig. 4). 


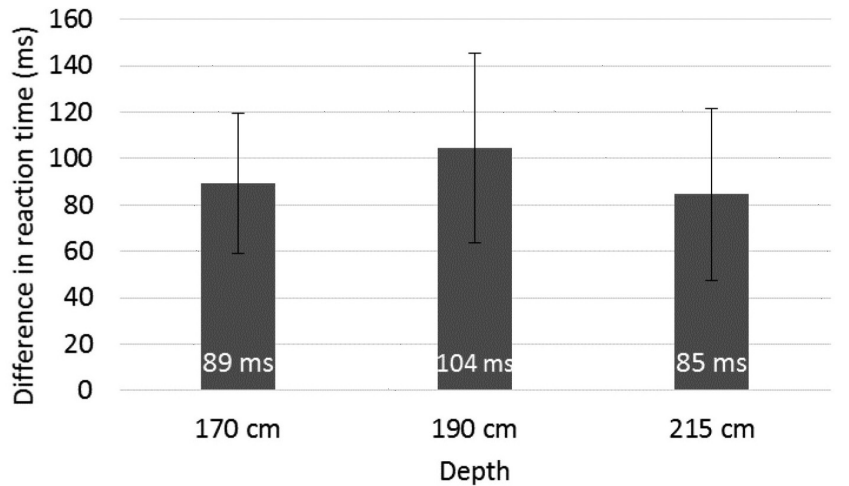

Fig. 5. Effects of reaction time in respective depths. The effects were calculated by subtracting reaction time for isolated targets from reaction time for flanked targets, separately for each depth condition. Error bars refer to standard deviations of the difference values. The depth of fixation was at $190 \mathrm{~cm}$.

Reaction times. To receive more insight about stimulus processing in the different conditions, we also analysed reaction times. Again, a 2 (context) $\times 3$ (depth) repeated measures ANOVA was conducted on reaction times. The results revealed an effect of context, $\mathrm{F}(1.16)=116.12, p=0.001$, $\eta^{2}=0.88$, indicating that reaction time for flanked targets was longer, than for isolated targets. Mean values $( \pm$ SD) at the fixation depth $190 \mathrm{~cm}$, were $599 \mathrm{~ms}( \pm 54 \mathrm{~ms}$ ) for isolated, and $704 \mathrm{~ms}( \pm 61 \mathrm{~ms})$ for flanked targets. In the 170 $\mathrm{cm}$ depth, mean reaction time was $602 \mathrm{~ms}( \pm 45 \mathrm{~ms})$ for isolated, and $691 \mathrm{~ms}( \pm 53 \mathrm{~ms})$ for flanked targets. In the 215 $\mathrm{cm}$ depth, mean reaction time was $609 \mathrm{~ms}( \pm 54 \mathrm{~ms})$ for isolated, and $694 \mathrm{~ms}( \pm 63 \mathrm{~ms})$ for flanked targets. For depth, the ANOVA showed no effect, $\mathrm{F}(2.32)=0.76, p=0.48$, but the interaction between context and depth was significant, $\mathrm{F}(2.32)=8.56, p=0.001, \eta^{2}=0.35$. This indicates that the difference in reaction times between isolated and flanked targets is larger in the fixation depth, than in defocused depths. In Figure 5 the effects of reaction times in respective depths are depicted.

\section{DISCUSSION}

In the present study the extent of the crowding effect was investigated, when stimuli are presented in different depths. For all tested depth planes, in front of, at, as well as behind the fixated depth, isolated and flanked stimuli were presented for $20 \mathrm{~ms}$ in the visual periphery, and at a constant eccentricity, with constant spacing. The results of the recognition performance indicated that the crowding effect in defocused depths (in front of, as well as behind fixation) was comparable to the fixation depth. Crowding effects were comparable also between the two tested defocused depths. Thus, regarding recognition performance, which is the variable usually used in crowding studies (Levi, 2008), we conclude that there is no difference in crowding in our range of depths. That means that the impact of depth is neglectable, when all stimuli are defocused within the tested range of depths. In our real three-dimensional setup defocus blur should be available as an indicator of depth. However, considering results about the depth of field, defocus blur might not have an effect, when we take into account the viewing distance and the relative distances of defocused depth planes and fixation depth (Campbell, 1957). Thus, stimuli were either not perceived blurry, or the degree of blur was pronounced not strong enough to affect crowding effects.

However, beyond recognition performance, our experimental paradigm enables more elaborated analysis of participant responses. Use of Landolt rings with four different opening directions allowed us to measure reaction time as an indicator of processing speed. In addition, since the opening direction of target and flanker stimuli, and also the opening direction of the two flanking stimuli were always incongruent, incorrect answers could be analysed in more detail. Therefore, incorrect answers were split into confusions with one of the flankers (inward or outward) and false responses.

Indeed, we found a tendency that the pattern of confusion errors differed between the fixation depth and the defocused depths: when flanked stimuli were presented at the fixation depth, more confusion with the inward than with the outward flanker emerged, whereas at both defocused depths this pattern was reversed. This suggests that inward flankers were more accessible at the fixation depth, whereas in defocused depths outward flankers were more accessible. Similar to our results at the fixation depth, Strasburger and Malania (2013) found for digits in a two-dimensional setup more inward confusions. Thus, the recognition mechanisms seem to be similar for stimuli at the fixation depth in both studies, whereas our study shows that processing in defocused depths might be different. It is assumed that positional uncertainty plays a substantial role in crowding effects (Huckauf and Heller, 2002a; 2002b). Strasburger (2005) claimed that especially imprecision in spatial attention are responsible for that. Confusion errors might reflect imprecise shifts in spatial attention. However, as we observed only a tendency, the basis to suggest selectively different spatial attention at the fixated and in defocused depths is rather thin.

Furthermore, also the results of reaction times showed a difference between the fixation depth and the defocused depths: the effect of flanking the target stimuli (mean reaction time difference between isolated and flanked stimuli) was pronounced stronger at the fixation depth than in the defocused depths. This stronger reaction time effect at the fixation depth could suggest that stimulus processing for flanked stimuli lasts longer at the fixation depth than in defocused depths. Combined with the trend to an asymmetry in confusion errors between fixation and defocused depths, one could suggest that depth triggers different processing mechanisms. However, a substantiated interpretation of these findings requires a replication of the effects. Moreover, there are several alternative explanations and restrictions that must be addressed.

Most important, the results of correct target identification suggests that recognition performance does not suffer from 
depth. At least, depth does not interfere to an extent that impairs the recognition performance. Nevertheless, interference form depth through defocus blur or binocular disparity could be reflected in reaction time differences. However, both depth cues should impair processing in defocused depths. This should be observed especially for flanked conditions, as for eccentricity (Bouma, 1970; Strasburger et al., 2011). Thus, effects of reaction times in defocused depths should be stronger. In contrast, our results indicate stronger reaction time effects at the fixation depth. Thus, our results might stem from attentional shifts. Remarkably, there were no differences in the results of confusion errors or reaction time between the depth plane in front of and the depth plane behind the fixation plane. Thus, concerning the results of the analysis of confusion errors and reaction time, the fixation depth stands out as a determining factor. Participant attention probably was more prone to defocused depths, since within the blocks stimuli were more likely to appear in the defocused depth (two-thirds of trials). Thus, when stimuli appeared at the fixation depth, participants additionally had to put effort into reorienting in depth, which is reflected in longer response latencies for target recognition at the fixation depth.

The current study is considered as a first attempt to apply the crowding paradigm in a real three-dimensional setup. However, it shows that our approach facilitates the investigation of manifold questions. Research on crowding, as well as research on depth perception can be enlarged and brought together. Our approach allows the investigation of the accuracy of peripheral visual object processing in real three-dimensional space. Our next studies will focus on the impact of real depth on peripheral object recognition in a broader range of depth. To disentangle the influence of defocus blur and binocular disparity on crowding, monocular and binocular observation can be compared.

Moreover, to further investigate the spatial extent of crowding, the distance between target and flankers in depth can be varied in future studies, i.e. only target, or only flanker stimuli can be defocused. Since former studies varied target to flanker distance in virtual depth, whereas we varied the distance of fixation depth and depth of crowded stimuli in a real depth setup, at this point, the basis for a comparison to these studies seems insufficient. Thus, a comparison of similar crowded stimulus configurations between our real three-dimensional and virtual depth environments should be aspired. This could help to integrate our results to the existing research on crowding in (virtual) depth (Astle et al., 2014; Felisberti et al., 2005; Kooi et al., 1994).

\section{CONCLUSIONS}

With the current study the crowding paradigm was successfully applied in a real three-dimensional experimental setup. In the first study it was shown that the crowding effect occurred to a similar extent over the tested range of depths. However, a more detailed analysis of confusion errors and reaction times revealed differences between the responses at the fixation depth and the defocused depth planes. Although the presented study represents only a first attempt, on its basis the manifold possibilities to expand research on peripheral visual object processing under special consideration of depth is demonstrated.

\section{ACKNOWLEDGEMENTS}

We thank Gabriel Yuras for spending many hours in programming the experimental code and supervising the data collection.

\section{REFERENCES}

Astle, A. T., McGovern, D. P., McGraw, P. V. (2014). Characterizing the role of disparity information in alleviating visual crowding. J. Vis., 14 (6), $1-14$.

Bernard, J. B., Arunkumar, A., Chung, S. T. (2012). Can reading-specific training stimuli improve the effect of perceptual learning on peripheral reading speed? Vis. Res., 66, 17-25.

Bortz, J., Schuster, C. (2010). Statistik für Human- und Sozialwissenschaftler. Berlin, Heidelberg: Springer-Verlag. 655 pp.

Bouma, H. (1970). Interaction effects in parafoveal letter recognition. $\mathrm{Na}$ ture, 226, 177-178.

Brainard, D. H. (1997). The psychophysics toolbox. Spatial Vis., 10, $433-436$.

Campbell, F. W. (1957). The depth of field of the human eye. J. Modern Opt., 4 (4), 157-164.

Felisberti, F. M., Solomon, J. A., Morgan, M. J. (2005). The role of target salience in crowding. Perception, 34 (7), 823-833.

Hoffman, D. M., Girshick, A. R., Akeley, K., Banks, M. S. (2008). Vergence-accommodation conflicts hinder visual performance and cause visual fatigue. J. Vis., 8 (3), 1-30.

Howard, I. P., Rogers, B. J. (2012). Perceiving in Depth, Volume 2: Stereoscopic Vision. New York: Oxford University Press. 648 pp.

Huckauf, A., Heller, D. (2002a). Spatial selection in peripheral letter recognition: In search of boundary conditions. Acta Psychol., 111 (1), 101-123.

Huckauf, A., Heller, D. (2002b). What various kinds of errors tell us about lateral masking effects. Vis. Cognit., 9 (7), 889-910.

Huckauf, A. (2007). Task set determines the amount of crowding. Psychol. Res., 71 (6), 646-652.

Huckauf, A., Nazir, T. A. (2007). How odgcrnwi becomes crowding: stimulus-specific learning reduces crowding. J. Vis., 7 (2), 1-12.

Kooi, F. L., Toet, A., Tripathy, S. P., Levi, D. M. (1994). The effect of similarity and duration on spatial interaction in peripheral vision. Spatial Vis., 8 (2), 255-279.

Korte, W. (1923). Über die Gestaltauffassung im indirekten Sehen. Zeitschrift für Psychologie, 93, 17-82.

Lambooij, M., Fortuin, M., Heynderickx, I., IJsselsteijn, W. (2009). Visual discomfort and visual fatigue of stereoscopic displays: a review. J. Imag. Sci. Technol., 53 (3), 1-14.

Levi, D. M. (2008). Crowding — An essential bottleneck for object recognition: A mini-review. Vis. Res., 48 (5), 635-654.

Pelli, D. G., Tillman, K. A. (2008). The uncrowded window of object recognition. Nature Neurosci., 11 (10), 1129-1135. 
Rinkenauer, G., Grosjean, M. (2008). Mapping the distribution of focused visual attention in real 3D space: Potential implications for interface design. Z. Arbeitswiss., 62 (3), 145-155.

Strasburger, H. (2005). Unfocussed spatial attention underlies the crowding effect in indirect form vision. J. Vis., 5 (11), 1024-1037.
Strasburger, H., Rentschler, I., Jüttner, M. (2011). Peripheral vision and pattern recognition: A review. J. Vis., 11 (5), 1-82.

Strasburger, H., Malania, M. (2013). Source confusion is a major cause of crowding. J. Vis., 13 (1), 1-20.

Received 24 October 2016

Accepted in the final form 24 September 2017

\section{PŪLAA EFEKTA IZPĒTE, IZMANTOJOT REĀLU TRĪSDIMENSIONĀLU EKSPERIMENTĀLO IEKĀRTU}

Parādība, kad perifērijā esošo vizuālo mērḳu atpazīšana ir zemāka, kad tiem apkārt ir līdzīgi stimuli, tiek saukta par pūḷa efektu. Līdzīgi pētîjumi divdimensionālā vidē parādīja, ka laterālās atstarpes ir svarīgas: pūḷa efekta lielums ir atkarīgs no mērḳa stimulu ekscentricitātes un attāluma starp mērḳi un blakus stimuliem. Jautājums, vai arī telpiskā attēlā attālumi analogi ietekmē pūla efektu, līdz šim tika pētîts, izmantojot tikai virtuālu dziļuma sajūtu. Tomēr virtuālā un reālā dziḷuma sajūta atškiriras, piemēram, saistībā ar akomodācijas-verğences mijiedarbību, kā arī saistībā ar apmiglojuma ietekmi. Līdz ar to mēs izmēǵinājām pêtīt pūḷa efektu, radot reālu dziḷuma sajūtu. Mūsu eksperimentā reāla dziḷuma sajūta tiek radīta, izmantojot divus monitorus, kurus dalībnieks redz, skatoties cauri puscaurspīdīgam spogulim. Tādējādi, mainot abu monitoru novietojumu attiecībā pret dalībnieku, var nodrošināt vienlaicīgu abu monitoru redzamību dažādos attālumos reālā telpā. Pirmajā pētījumā, kurā piedalījās 18 dalībnieki, fiksācijas krusts tika novietots $190 \mathrm{~cm}$ attālumā no dalībnieka. Atsevišḳi Landolta gredzeni un kopāa ar blakus stimuliem tika rādīti ar $2^{\circ}$ lielu ekscentricitāti tajā pašā dziḷumā kā fiksācijas krusts, tuvāk par to (170 $\mathrm{cm})$ vai tālāk $(215 \mathrm{~cm})$. Pūḷa efekts bija līdzīgs visiem trim stāvokliem — gan stimuliem, kas parādās vienā plaknē ar fiksācijas krustu, gan tiem, kas ir novietoti tuvāk vai tālāk nekā fiksācijas krusts. Savukārt atškịīiba reakcijas laikiem starp izolētu mērḳi un gadījumā, kad mērkis tika demonstrēts kopā ar blakus stimuliem, bija mazāka, ja stimuli tika rādīti tuvāk vai tālāk nekā plakne, kurā novietots fiksācijas krusts, salīdzinot ar gadījumiem, kad stimuli tika rādīti tajā pašā plaknē kā fiksācijas krusts. Tas nozīmē, ka reakcijas laiki bija augstāki, demonstrējot stimulu plaknē, kurā atradās fiksācijas krusts, nekā demonstrējot stimulus pirms vai aiz šis plaknes. Izmantojot šo eksperimentālo iekārtu, pūla efekts tika veiksmīgi inducēts reālā telpā. Turpmākajos pētījumos tiks novērtēta izolēta mērķa un mērkia kopā ar blakus stimuliem ietekme uz pūḷa efektu, ja tiek pielietoti citi attālumi reālā telpā. 